\title{
PENGEMBANGAN USAHA KECIL MENENGAH DI INDONESIA MELALUI PERAN BANK SYARIAH
}

\author{
${ }^{1}$ Eddy Suratno \\ ${ }^{1}$ Staff pengajar STIKOM Dinamika Bangsa Jambi
}

\begin{abstract}
Indonesia is one of the countries of the third world countries are categorised are still in the developing stage. In the context of developing countries, the system state economy often rely against capital assistance from outside the country. This has a lotof bearing controversial in a country life order. On the pretext of collaboration withforeign parties in relation to capital assistance to help grow the economy of the country, it was important for this pretext away from the purpose originally, the contraryhas been spoiling the nation own to keep dependent against help-the help is always given by the outside parties to us, so that we can feel the implication itself i.e. the lack of independence of the US to build our own nation. The crisis that hit the nation of Indonesia has had floods in all joints, including the banking sector lives also on view as one trigger, i.e. with credit-credit disalurkannya the wrong target. The crisis proved that the number of small and medium businesses are very much able to survive the crisis facing independently. While the economy has now started shows stretching to bounce back, it seems as if the medium-small business back into oblivion, especially with many entry and operation of foreign businesses - including foreign sales period of post-war banking assets national banking. Islamic banking which has been established since the year 1992 apparently can now be renewed hope for the small and medium enterprise development, especially in the procurement of working capital.
\end{abstract}

Keywords: Islamic Banking, Small Business

\section{PENDAHULUAN}

Indonesia sebagai negara dengan penduduk muslim terbesar di dunia, juga tidak terlepas dari perkembangan ini. Perkembangan ekonomi Islam di Indonesia antara lain ditandai dengan munculnya Bank Muamalat Indonesia, sebagai bank yang beroperasi dengan sistem syariah pertama di Indonesia pada 1992. Munculnya perbankan syariah di Indonesia merupakan suatu perwujudan dari permintaan masyarakat yang membutuhkan suatu sistem perbankan alternatif yang selain menyediakan jasa perbankan/keuangan yang sehat, juga memenuhi prinsip-prinsip syariah. Kemunculan bank syariah kemudian diikuti dengan kemunculan lembaga keuangan syariah lainnya, seperti asuransi syariah, pegadaian syariah, saham syariah maupun berbagai model keuangan lainnya.

Indonesia adalah salah satu Negara yang terkategori Negara dunia ketiga yang masih dalam tahap berkembang. Dalam konteks Negara berkembang, sistim perekonomian Negara sering kali bergantung terhadap bantuan modal yang berasal dari luar Negara. Hal ini telah banyak melahirkan controversial dalam tatanan kehidupan bernegara. Dengan dalih kerjasama dengan pihak asing dalam kaitannya menerima bantuan modal untuk membantu tumbuh kembangnya perekonomian Negara, ternyata selama ini dalih tersebut jauh dari

Pengembangan Usaha Kecil Menengah di Indonesia Melalui Peran Bank Syariah 
tujuan awalnya, malah sebaliknya langkah tersebut telah memanjakan bangsa sendiri untuk tetap bergantung terhadap bantuan- bantuan yang selalu diberikan oleh pihak luar tersebut kepada kita, sehingga implikasinya dapat kita rasakan sendiri yaitu kurangnya kemandirian kita untuk membangun bangsa kita sendiri.

Krisis yang melanda bangsa Indonesia telah meluluh lantakkan segala sendi-sendi kehidupan termasuk juga sektor perbankan yang juga di pandang sebagai salah satu pemicunya, yaitu dengan disalurkannya kredit-kredit yang salah sasaran. Krisis membuktikan bahwa usaha kecil menengah yang jumlah sangat banyak mampu bertahan menghadapi krisis tersebut secara mandiri. Disaat perekonomian kini mulai menunjukkkan geliat untuk bangkit kembali, usaha kecil menengah nampaknya seolah kembali terlupakan, terutama lagi dengan banyak masuk dan beroperasinya usaha asing - termasuk perbankan asing pasca periode penjualan aset-aset perbankan nasional. Perbankan syariah yang telah dirintis sejak tahun 1992 nampaknya kini dapat menjadi harapan baru bagi pengembangan usaha kecil menengah, khususnya dalam pengadaan modal kerja.

Dari peristiwa krisis yang telah melanda bangsa Indonesia tersebut telah menciptakan kemiskinan bagi sebagian kalangan masyarakat kita yang sifatnya terstruktur, melalui pemberdayaan perbankan syariah ini harapan kita akan bisa menangani kemiskinan dengan menghilangkannya melalui proses trickle down effect. Akibatnya kemungkinan terjadinya ketimpangan distribusi dan akses sumber daya ekonomi. Karena pendekatan ini butuh biaya besar dan harus ditanggung oleh negara ( mengandalkan pinjaman luar negeri ).

Untuk mengatasi permasalahan yang telah terjadi selama ini terhadap Negara kita yang selalu mengandalkan ketergantungan kepada bantuan dari luar nergeri salah satu langkah yang dianggab efektif adalah menggunakan keuangan mikro sebagai metode utama. Kontribusi pendekatan ini terdiri dari diversifikasi pelaku utama pembangunan adalah masyarakat, pembiayaan pembangunan yang menggunakan sumber keuangan masyarakat sendiri serta menerapkan pendekatan pembangunan yang memiliki potensi untuk berlanjut (sustainable).

Beranjak dari permasalahan itu, kita sebagai Subyek yang akan menentukan masa depan bangsa kita tidak akan mingkin bergantung secara terus menerus terhadap upaya- upaya tersebut. Kita harus berupaya mencari terobosan- terobosan lain yang justru memberikan harapan yang lebih menjanjikan terhadap masa depan perekonomian kita. Saat sekarang ini seiring dengan berkembangnya pola pikir masyarakat Indonesia pada umumnya, telah bisa melahirkan terobosan- terobosan baru dalam rangka pengembangan ekonomi bangsa, dari banyak terobosan- terobosan tersebut salah satunya dapat kita amati dari segi perkembangan sector Asaha Kecil dan Menengah.

Ketika kita menelaah lebih jauh dari kondisi perkembangan perekonomian masyarakat kita, bahwasanya ekonomi rakyatlah yang akan menjadi benih awal yang akan meujutkan perekonomian nasional yang akan memberikan kontribusi bagi masyarakat kita sendiri dalam usaha pengembangan kearifan local. Ujut konkrit dari berkembangnya ekonomi rakyat yang diujutkan dalam bentuk Usaha Kecil Menengah ini kalau kita mencoba menelaah lebih jauh, ternyata yang berperan dibalik itu semua selama ini salah satunya adalah peranan Bank Syariah yang selalu memberikan kontribusi dalam usaha pengembangan 
perekonomian rakyat itu sendiri. Selama ini langkah dari Bank Syariah telah memberikan semangat dan dorongan terhadap terujut dan terbangunnya semangat para masyarakat Indonesia yang berasal dari kalangan menengah kebawah yang ingin mencoba ikut serta dalam upaya meujutkan perekonomian bangsa yang berorientasi kedepan dan bermasa depan yang jelas yang sesuai dengan harapan masyarakat kecil pada umumnya. Itu semua telah diujutkan dengan upaya pengembangan Usaha Kecil Menengah yang benar- benar mengembangakan potensi ekonomi yang ada dalam tubuh masyarakat itu sendiri.

\section{Definisi dan Sejarah awal munculnya Perbankan Syariah dalam upaya} pengembangan Usaha Kecil Menengah.

a. Definisi dari Perbankan Syariah

Perbankan Syariah atau perbankan Islam adalah suatu sistem perbankan yang dikembangkan berdasarkan syariah (hukum) Islam. Usaha pembentukan sistem ini didasari oleh larangan dalam agama Islam untuk memungut maupun meminjam dengan bunga atau yang disebut dengan riba serta larangan investasi untuk usaha-usaha yang dikategorikan haram (misal : usaha yang berkaitan dengan produksi makanan/minuman haram, usaha media yang tidak Islami dll), dimana hal ini tidak dapat dijamin oleh sistem perbankan konvensional.

b. Sejarah singkat awal munculnya Perbankan Syariah dalam upaya pengembangan Usaha Kecil Menengah

Perbankan syariah pertama kali muncul di Mesir tanpa menggunakan embel-embel Islam karena adanya kekhawatiran rezim yang berkuasa saat itu akan melihatnya sebagai gerakan fundamentalis. Perintis usaha ini Ahmad El Najjar mengambil bentuk bank simpanan yang berbasis profit sharing di Kota Mit Ghamr pada tahun 1963. Eksperimen ini berlangsung hingga tahun 1967 dan saat itu sudah berdiri sembilan bank dengan konsep serupa di Mesir.

Tahun 1970-an, sejumlah Bank berbasis Islam kemudian muncul. Di Timur Tengah misal berdiri Dubai Islamic Bank (1975), Bank of Sudan (1977), Philipine Amanah Bank (1973) dan Malaysia dengan Muslim Pilgrims Savings Corporation (1983).

c. Keberadaan Perbankan Syariah di Indonesia

Di Indonesia, pelopor Perbankan Syariah adalah Bank Muamalat Indonesia (MUI) dan pemerintah dengan dukungan dari ICMI. Berdiri pada tahun 1991.Diatur dengan UU No. 10 tahun 1998. Hingga tahun 2007, terdapat institusi Bank Syariah di Indonesia yaitu Bank Muamalat Indonesia, Bank Syariah Mandiri, dan Bank Mega Syariah. Produk jasa yang disediakan bank syariah : musharabah (perjanjian antara penyedia modal dengan pengusaha), musharakah (joint venture/ada campur tangan pengelolaan manajemen), murabahan (penyaluran dana dalam bentuk jual beli) dan Takaful (asuransi Islam).

\section{Peran Bank Syariah dalam pengembangan Usaha Kecil Menengan di Indonesia.}

Berdirinya Bank Syariah dalam upaya pengembangan Usaha Kecil Menengan di Indonesia awalnya tidak terlepas dari peran yang telah 
dilakukan oleh Bank- Bank yang lain yang telah ada sebelumnya di Negara kita ini. Dimana Bank- Bank tersebut kebanyakan mereka hanya mau meminjamkan uang atau membuka kredit kepada orang yang sudah punya "uang" dalam arti penghasilan dan aset., kesalahan pola berfikir inilah yang dirubah oleh Muhammad Yunus yang awalnya semua itu dikemas dengan berdirinya Grammen Bank.

Grammen Bank (Grammen berarti pedesaan) yang lebih kita kenal selama ini ujut konkriknya dalam konteks Bank Syariah. Dimana institusi ini didirikan pada tahun 1976 dengan idealisme menciptakan sistem pelayanan keuangan bagi masyarakat miskin berlandaskan rasa saling percaya, akuntabilitas, partisipasi dan kreativitas. Kegiatan yang bersifat proyek itu ditransformasikan menjadi bank di bawah aturan hukum yang khusus dibuat untuk kreasi pemikiran pengentasan masyarakat dari kemiskinan

Ketika kita mencoba melihat dalam satu decade terakhir ini, bisnis perbankan konvensional di Indonesia mulai tersaingi dengan kehadiran Bank Syariah. Bank Syariah menawarkan alternative jasa perbankan dengan system imbalan berupa bagi hasil ( profit and loss sharing principle ) atau Profit Margin yaitu keuntungan yang diharapkan oleh Bank Syariah, system ini menerapkan prinsip keadilan antara pihak Bank maupun nasabah. Bermula dari jasa penghimpunan dana masyarakat dalam bentuk tabungan dengan prinsip syariah, kini Bank syariah mulai merambah bisnis pembiayaan untuk modal usaha maupun pembayaran yang bersifat konsumtif.

Filosofi Model Bank Syariah adalah Credit is fundamental right (Kredit adalah hak bagi setiap orang) untuk mendapatkannya termasuk orang miskin guna memberikan kesempatan untuk meningkatkan pendapatan dan memenuhi semua keperluan hidupnya dalam hal ini diujutkan dalam benrtuk terciptanya Usaha Kecil Menengah yang berusaha mengobtimalkan sumber daya yang ada dalam masyarakat kecil itu sendiri yang selama ini belum tersentuh oleh langkah Pemerintah.

Prinsip Filosofi Dasar Bagi Pengembangan Bank Syariah dalam upaya pengembangan Usaha Kecil Menegah yang ada dalam masyarakat adalah, bantuan yang diberikan tanpa jaminan atau penjamin, target kelompok adalah masyarakat kecil miskin yang kurang mampu yang mempunyai potensi untuk mengembangkan usaha perekonomiannya serta ketentuan lain yang juga diterapkan adalah jika anggota meninggal dunia, mereka dibebaskan dari pembayaran kredit

Dalam menjalankan program pelayanan kredit mikronya, Bank Syariah mengorganisasir masyarakat miskin yang menjadi peminjamnya dalam kelompok-kelompok kecil yang terdiri atas lima anggota. Tujuannya, memperkuat para peminjam sehingga mereka mempunyai kapasitas untuk merencanakan dan melaksanakan pengambilan keputusan di tingkat mikro. Centre (kumpulan kelompok) juga dibentuk sebagai media penghubung dengan kantor cabang di mana petugas lapangan Bank Syariah harus menghadiri pertemuan centre setiap minggu. Sementara dalam hal penyaluran kredit, tetap diprioritaskan pada kelompok masyarakat yang benar- benar membutuhkan dana untuk menunjang keberhasilan usahanya. Upaya Bank 
Syariah dalam pengembangan Usaha Kecil Menengah yang ada dalam masyarakat kita dalam hal pemberian bantuan, Bank Syariah mengfokuskan prioritasnya kepada pemberian kredit tidak didasarkan atas kedermawanan atau belas kasihan, sebab akan menyebabkan terjadinya ketergantungan pada pihak lain. Serta bantuan kredit yang telah diberikan harus dapat menyiapkan persyaratan dan prosedur kredit yang sesuai dengan kondisi masyarakat (fleksibel).

Disamping itu bantuan kredit yang diberikan oleh Bank Syariah tidak mensyaratkan adanya agunan atau jaminan anggota. Yang lebih menariknya dari kebijakan Bank Syariah ini dalam upya memberikan bantuan dana kepada masyarakat kecil adalah terkait dengan pengelolaan bantuan kredit itu sendiri harus dilakukan secara terbuka dan profesional dengan berprinsip dari, oleh dan untuk anggota. Dan juga dalam pelaksanaan programnya, berusaha memanfaatan kelompok-kelompok yang sudah ada di masyarakat sebagai sarana penyalur bantuan kredit.

Bagi industri perbankan yang dalam hal ini adalah Perbankan Syariah, proses penyaluran pembiayaan yang mereka lakukan terhadap sektor UKM lebih menguntungkan dibandingkan sektor non UKM. Seba, sektor UKM memiliki ketahanan bisnis lebih kuat.

Disamping itu factor pendukung lainnya yang juga akan menguntungkan Perbankan Syariah yaitu terkait dengan pembiayaan UKM yang saat sekarang ini mendapat alokasi bantuan yang besar dari pemerintah terkait dengan pengembangan UKM tersebut, karena alokasi pembiayaan yang cukup besar tersebut lahir dan dipicu oleh keinginan pemerintah agar industri perbankan nasional memiliki kontribusi lebih besar dalam mendorong perkembangan sektorUKM.

Beranjak dari semua itu, kami sebagai penulis yakin sekali bahwasanya UKM ini berpotensi cukup besar bagi perkembangan Perbankan Syariah karena bisa kita lihat bersama dengan mengingat kembali dari masa krisis moneter ke pasca krisis moneter, UKM itu terbukti selalu menjadi tulang punggung perekonomian kita. Sektor UKM memiliki daya tahan yang lebih kuat dalam menghadapi krisis, dibandingkan sektor lain. Hanya memang, pemerintah masih kurang memberikan dukungan. Karena itulah bank syariah seharusnya juga masuk ke sana. Kami optimistis, bisnis perbankan syariah, dengan mendukung pengembangan UKM, akan lebih besar dan akan selalu eksist kedepannya.

\section{SIMPULAN}

Solusi yang kami tawarkan terkait dengan peran Bank Syariah dalam upaya pengembangan Usaha Kecil Menengah yang ada di Indonesia

1. Pinjaman dalam bentuk micro credit merupakan salah satu upaya yang ampuh dalam menangani kemiskinan seperti yang telah diterapkan selama ini oleh Bank Syariah dalam upaya pengembangan Usaha Kecil Menengan dalam masyarakat kita. Hal ini didasarkan bahwa masyarakat miskin dapat diklasifikasikan ke dalam tiga hal yaitu pertama, masyarakat yang sangat miskin,mereka yang tidak punya penghasilan dan tidak memiliki kegiatan produktif. kedua, masyarakat yang dikategorikan miskin namun memiliki 
kegiatan ekonomi dan ketiga, masyaraakt yang berpenghasilan rendah yakni mereka yang memiliki penghasilan meskipun tidak banyak. Bagi kelompok pertama, tepat digunakan pendekatan langsung berupa program pangan, subsidi atau penciptaan lapangan kerja. Sedangkan bagi kelompok kedua dan ketiga lebih efektif, jika digunakan pendekatan tidak langsung misalnya penciptaan iklim yang kondusif bagi pengembangan UKM, pengembangan berbagai jenis pinjaman mikro atau mensinergikan UKM dengan para pelaku usaha menengah atau besar.

2. Pemerintah memfasilitasi tersedianya bantuan manajemen/teknis kepada para Bank Syariah yang dinilai memiliki potensi untuk memberikan pelayanan kepada penduduk miskin dalam usaha ekonomi produktif.

3. Pemerintah menyediakan infrastruktur yang mendukung penguatan lembaga keuangan mikro yang dalam hal ini adalah Bank Syariah yang telah ada, langkah yang harus diterapkan adalah dengan membuat produk hukum yang melindungi keberadaab Bank Syariah, jaringan-jaringan informasi dan peraturan yang memperkuat keberadaan Bank Syariah ( Munculnya UndangUndang yang sah terkait keberadaan Bank Syariah ini ).

4. Pemerintah menyiapkan iklim yang mendukung bagi perkembangan Bank Syariah melalui kebijakan dan regulasi fiskal, moneter dan perbankan. Melalui kebijakan dan regulasi tersebut diarahkan agar Perbankan juga memposisikan keberadaan Bank Syariah yang juga potensial untuk maju sebagai mitra bisnisnya.

5. Untuk menghindari penyalahgunaan bantuan dana yang telah diberikan oleh pihak Perbankan Syariah kepada para nasabah, sekiranya perlu dilakukan observasi terhadap para peserta yang akan menerima bantuan dari Perbankan Syariah tersebut dan dari sisi pendanaan diperlukan skema pembiayaan UKM yang sesuai dengan kondisi dan kebutuhan masing-masing jenis usaha mikro, kecil dan menengah tersebut, dengan asumsi dana yang akan dikucurkan tersebut sesuai dengan jumlah dana yang menjadi kebutuhan dari UKM itu sendiri. Kadang kita lupa bahwa yang termasuk kategori UKM tersebut bukan hanya industri kecil atau pedagang kecil saja. Para petani sebagai pemilik dan pengelola lahan serta nelayan juga termasuk dalam kategori ini.

6. Dari sisi manajemen, banyak UKM yang masih membutuhkan bantuan manajemen dan pendampingan usaha. Minimnya pengalaman dan pengetahuan manajemen UKM menjadikan kucuran kredit yang diperoleh tidak menjamin keberhasilan usahanya.

7. Perlunya pihak perbankan syariah memberikan penyuluhan terkait dengan kemampuan pemasaran yang baik. Banyak produk yang dihasilkan UKM tidak dapat diserap pasar karena kemampuan pemasaran UKM yang kurang memadai.

8. Diperlukannya teknologi yang tepat guna untuk memenuhi persyaratan kualitas dan permintaan kuantitas produk dari para UKM yang diinginkan oleh pasar, langkah ini bisa dilakukan oleh pihak perbankan syariah sendiri dalam rangka pemberian penyuluhan dan penerangan terhadap para nasabah sebagai penerima bantuan agar bantuan yang telah diberikan akan lebih berarti dan sesuai denga tujuan dan sasaran yang diinginkan. 
Untuk mengatasi hal-hal tersebut di atas, dalam pengembangan UKM di masa mendatang hendaknya dari pihak perbankan syariah yang dalam hal ini sebagai badan penyalur dan sekaligus pemberi bantuan terhadap para nasabah ( masyarakat kalangan menengah ke bawah) harus bisa menekankan kepada para nasabah terkait dengan perkembangan usahanya sendiri yaitu harus ada suatu program yang lebih jelas dan terencana, baik untuk jangka pendek, menengah maupun panjang.

Jika langkah diatas tidak bisa dilakukan, maka daya saing produk kita akan tambah jauh tertinggal dari produk-produk import yang saat ini sudah mulai membanjiri pasar Indonesia. Jika perkembangan UKM tersebut dapat berjalan dengan baik produk yang dihasilkan akan dapat menggantikan produkproduk impor yang membebani devisa negara, serta secara bersamaan dapat menjadi produk ekspor yang menghasilkan devisa negara

Penulis sendiri berpendapat bahwa yang paling penting adalah tetap memelihara "obor" semangat menuju terwujudnya ekonomi Islam yang sejati. Bentuk, proses, sistem dan mekanisme yang selama ini ada merupakan "realitas empiris" yang perlu didukung untuk perkembangan menuju kesempurnaan sistem keuangan Islam. Ide, riset dan alternatif-alternatif dapat berjalan dengan baik ketika terdapat sinergi antara dunia akademis, lembaga akademis lainnya, lembaga-lembaga keuangan sebagai representasi empiris, dunia bisnis, pemerintah, DSN-MUI, serta masyarakat secara umum.yang dalam hal ini sangat terlihat sekali peranannya dalam pengembangan perekonomian masyarakat yang diujutkan dalam bentuk pemberian bantuan- bantuan kepada Asaha Kecil Menengah yang dalam decade ini menjadi sector ekonomi andalan bangsa kita.

Kami juga masih percaya bahwa kekuatan berusaha terdapat pada sifat enterpreneurship yang berhubungan dengan Trust. Trust bukan hanya kepercayaan pada tingkatan "deadline kewajiban" yang misalnya diukur dalam bentuk CAMEL perbankan, atau kemampuan menjalankan manajerial secara profesional. Trust substantif jelas lebih dari itu, yaitu Trust berdasar hati dan ketundukan, dalam Capaian Ketuhanan.

\section{DAFTAR PUSTAKA}

Bank Indonesia. Statistik Perbankan Syariah. Jakarta: Mei 2007. Bank Indonesia. Laporan Perkembangan Perbankan Syariah Tahun 2006. Jakarta: 2007.

Chapra, M. Umer. "Monetary Management in an Islamic Economy". Islamic Economics Studies, Vol. 4, No. 1, December 1996.

Chapra, M. Umer. Masa Depan Ilmu Ekonomi: Sebuah Tinjauan Islam, terj., Jakarta: Gema In ani Press, 2001. Bank Indonesia, (2002), Cetak Biru Pengembangan Perbankan Syariah di Indonesia, Direktorat Perbankan Syariah: Jakarta.

(2007) Laporan Perkembangan Perbankan Syariah 2006, Direktorat Perbankan Syariah: Jakarta.

Febrinol, Tisna Surya Adi Prenanto dan Riyadian Dwi Cahyo, Artikel 25 sep 2012 
El Diwany, Tarek. The Problem with Interest, 2nd ed., London: Kreatoc Ltd., 2003.

Gardner, H. Stephen. Comparative Economic Systems, 2nd ed., Orlando: The Dryden Press, 1998.

Qaradhawi, Yusuf. Peran Nilai dan Moral dalam Perekonomian Islam, terj., Jakarta: Robbani Press, 2001.

Suharto, Ugi. Keuangan Publik Islam: Reinterpretasi Zakat dan Pajak. Yogyakarta: Pusat Studi Zakat, 2004.

Swasono, Sri Edi. Ekspose Ekonomika: Mewaspadai Globalisme dan Pasar Bebas. Yogyakarta: Pustep-UGM, 2005.

Wibisono, Yusuf. "Era Baru Perbankan Syariah: Dampak UU Perbankan Syariah Terhadap Prospek Industri Perbankan Syariah Nasional”. Makalah disampaikan pada Seminar Menyongsong Kehadiran UU Perbankan Syariah, FHUI Depok, 9 April 2007. 